\title{
Utilization of Admixtures in Self-Compacting High Performance Concrete
}

\author{
Sakshi Gupta, Rishabh N. Mahure, Ankit Batra
}

\begin{abstract}
Flowable concrete or self-consolidating or self-compacting concrete (SCC) is a particularly flowable, non-segregating concrete which flows, plugs formwork, and captures the utmost congested rebars with none use of mechanical vibration. When used with admixtures to enhance the performance of concrete, it is called as self-compacting high performance concrete. An extant literature survey was taken up to understand the utilization of waste polyethene, fly ash and micro-silica in SCC to make it a SCHPC. It has been seen that very less amount of research work is available on use of waste polythene in conventional concrete as well as SCC. A few studies have reported positive results towards the mechanical properties i.e. compressive strength and flexural strength of concrete while no literature is available taking into account its initial cost and the durability aspects of such concrete.
\end{abstract}

KEYWORDS- SCC, concrete, high performance, flowable, construction

\section{INTRODUCTION}

Flowable concrete or self-consolidating or self-compacting concrete (SCC) is a particularly flowable, non-segregating concrete which flows, plugs formwork, and captures the utmost congested rebars with none use of vibration. SCC is defined as a concrete that can be positioned decently with the help of its self-weight without any vibration which results in pouring of SCC as much less labour-intensive in comparison to normal (standard) concrete mixes. SCC is generally comparable to the normal concrete with respect to its setting and curing time, and strength; once poured. SCC was theorized in the year 1986 by Okamura, who is a professor at Ouchi University,

\section{Manuscript received May 21, 2020}

Sakshi Gupta, Department of Civil Engineering, Amity School of Engineering \& Technology, Amity University Haryana, India-122413 (email: sgupta6@ggn.amity.edu)

Rishabh Mahure, Department of Civil Engineering., Noida International University, Gr. Noida, Uttar Pradesh, India

Ankit Batra, Department of Civil Engineering, Amity School of Engineering \& Technology, Amity University Haryana, India-122413
Japan. During that time, the skilled labours were inadequate in supply and leading to complications in concrete and construction industries. The early practical form of SCC was manufactured in 1988 and was termed as High Performance Concrete (HPC), and later was anticipated to be termed as Self-Compacting High Performance Concrete (SCHPC).

The usage of chemical admixtures has always been essential when manufacturing SCC so as to enhance the workability and decrease segregation. As compared to normal concrete, the amount of coarse aggregate and the water to binder ratio in SCC are lesser. Consequently, SCC comprises of huge quantity of fine particles such as micro-silica, nano-silica, blast-furnace slag, fly ash, etc. to evade the gravity segregation of large particles in the freshly prepared SCC mix. SCC brings striking advantages while sustaining all the expected mechanical and durability properties of the concrete [1][2].

\section{UTILIZATION OF WASTE POLYTHENE, MICRO-SILICA AND FLY ASH IN SCHPC}

\section{A. Waste Polyethene}

As per the recent studies, one of the fastest growing industry is the plastic industry and nearly about 1.2 trillion plastic bags per annum are being utilized around the globe. This is just a single example of plastic products whereas there are a number of plastic goods used in the everyday life. Discarding of polythene wastes is a gigantic issue as plastic is non-renewable and non-biodegradable and pollutes the environment. The chemical bonds of polythene increases its resistance in contradiction to the natural procedure of degradation. Plastic material especially, polythene, has become an indispensable part of our everyday life that rises the amount of plastic wastes which either mixes with municipal wastes or landfilled in abundance. The dumping of plastic waste by land-filling or by incineration methods have substantial adverse effects on the environment i.e. it leads to land, air and water pollution. Plastic bags have adversative influences on our natural habitats and also have been found to be accountable for the demise of a number of animals due to suffocation encountered by them after eating the plastic. Plastic bags can last for hundreds of years and therefore there is a need to find alternative option for the same to curb the ill-effects of plastics on various species and environment as a whole [3][4][5][6][7][8][9][10][11][12]. Various researchers have come up with the theoretical overview of utilization of 
plastic waste in concrete of various kind in different aspects.

\section{B. Micro Silica}

It is a mineral admixture that comprises of vitreous solid glassy particles (spherical) of $\mathrm{SiO}_{2}$. Most of the micro-silica units are less than 0.00004 inch diametrically which is usually 50 to 100 times finer than an average cement and even fly ash particles. In construction and manufacturing industry, it is generally known as condensed silica fume which is a by-product of the engineering of ferro-silicon and metallic silicon at high-temperature in furnaces (electric arc). The utilization of micro-silica creates a lot of changes in the strength and durability in concrete by acting in two different ways. Firstly, as a pozzolan, it offers an additional

uniform distribution of the particles and a superior size of hydration products. Secondly, when it is used as a filler, it reduces the average pore size in the paste (cement + water). When utilized as an admixture, it can enhance various properties of concrete such as fresh, workability, mechanical and durability properties. With the addition of micro silica, the rate of carbonation is reduced while it diminishes the permeability to chloride ions. It possesses high electrical resistivity, and has slight consequence on oxygen transport. When it is utilized as a partial replacement for cement, it can additionally provide advantages for energy-consuming cement without compromising with the quality of concrete [2][13][14][15] [16][17][18][19][ 20][21].

\section{Fly Ash And Red Mud}

Pulverized fuel ash or Fly ash, is a by-product of coal combustion (thermal power station) comprised of the particulates of fuel that are gushed out of coal-fired boilers along with the flue gases. The ingredients of fly ash vary substantially which depends upon the type as well as source of the coal that is burnt. Almost all fly ash contains considerable quantities of $\mathrm{SiO}_{2}, \mathrm{Al}_{2} \mathrm{O}_{3}$ and $\mathrm{CaO}$ as the constituents. In relation to the sustainable development, it is imperious that additional cementitious materials must be utilized to substitute the huge amounts of cement in the construction industry.

On the other hand, red mud is a by-product of Bayer's process employed in alumina production. To significantly increase the utilization of fly ash and red mud which are by-products and being wasted, and to have a substantial influence on the powder content of concrete, it is essential to utilize the concrete incorporating huge quantities of fly ash and red mud as replacements of cement. Such concretes as per the literatures show good performance as compared to the normal concrete, and can be made cost effective and efficient [1][22][23][24][25][26]

\section{LITERATURE SURVEY}

Various researchers had worked on the different properties of the SCC and also with supplementary cementitious materials and waste materials which is called SCHPC. But as such the research on consumption of waste plastic bags in concrete has been carried out in very few areas.
The summary of the researches being carried out by various researchers is mentioned in Table 1.

Brief literature on the properties of waste polythene gives very limited information utilization of waste polythene in SCC. The information available till date is insufficient to study the effects of waste polythene on different properties of self-compacting concrete.

Table 1: Summary of the research on self-compacting high performance concrete using various admixtures

\begin{tabular}{|c|c|c|}
\hline S.No. & $\begin{array}{c}\text { Researcher(s) } \\
\text { (year) }\end{array}$ & Work carried out \\
\hline 1. & $\begin{array}{l}\text { Persson } \\
(2000)[3]\end{array}$ & $\begin{array}{l}\text { - Assessed the mechanical } \\
\text { properties (strength, elastic } \\
\text { modulus, creep and } \\
\text { shrinkage) of SCC and also } \\
\text { for NCC. } \\
\text { - Used } 8 \text { mix proportions } \\
\text { with w/b ratio ranging from } \\
0.24 \text { to } 0.80 \text {. } \\
\text { - Half of the mixes were SCC } \\
\text { and other half NCC. } \\
\text { - In the creep study, the } \\
\text { loading age varied in the } \\
\text { ranges of } 2 \text { and } 90 \text { days. } \\
\text { Results revealed that elastic } \\
\text { modulus, creep and } \\
\text { shrinkage of SCC did not } \\
\text { differ to a great extent as } \\
\text { compared to NCC. }\end{array}$ \\
\hline 2. & $\begin{array}{l}\text { Bouzoubaa } \\
\text { and Lachemi } \\
(2001)[22]\end{array}$ & 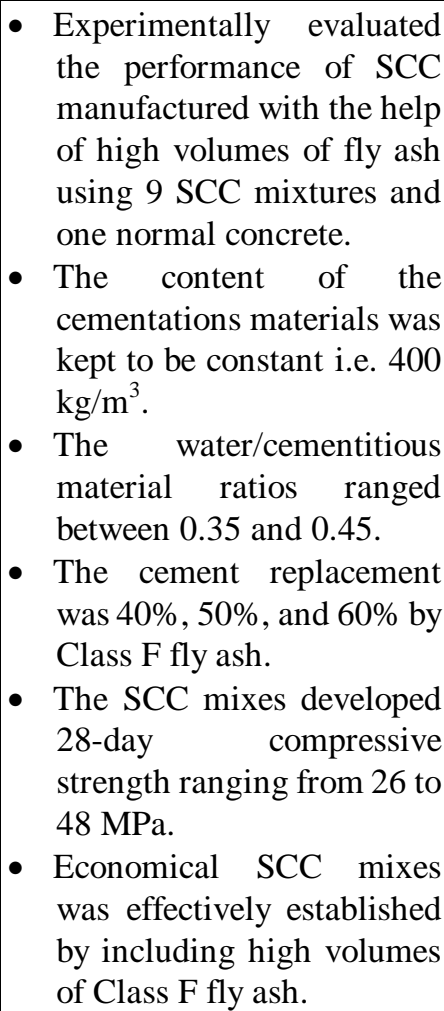 \\
\hline 3. & $\begin{array}{l}\text { Felekoglu et } \\
\text { al. (2006) [4] }\end{array}$ & $\begin{array}{l}-5 \text { mixes with diverse blends } \\
\text { of w/c ratio and different } \\
\text { dose of super plasticizer } \\
\text { were carefully prepared and } \\
\text { tested. }\end{array}$ \\
\hline
\end{tabular}




\begin{tabular}{|c|c|c|}
\hline & & $\begin{array}{l}\text { - Results revealed that the } \\
\text { optimum w/c ratio for } \\
\text { manufacturing SCC was in } \\
\text { the range of } 0.84 \text { to } 1.07 \text { by } \\
\text { volume. } \\
\text { - }\end{array}$ \\
\hline 4. & $\begin{array}{lrr}\text { Grdic et } & \text { al. } \\
(2008) & {[5]}\end{array}$ & $\begin{array}{l}\text { - } \text { Carried out an } \\
\text { investigational study on } \\
\text { the properties of SCC } \\
\text { mixed with various kinds of } \\
\text { additives such as fly ash, } \\
\text { silica fume, hydraulic lime } \\
\text { and a mixture of fly ash and } \\
\text { hydraulic lime. } \\
\text { - Results revealed that } \\
\text { adding of fly ash to the mix } \\
\text { containing hydraulic lime } \\
\text { is fairly advantageous } \\
\text { leading to a significant } \\
\text { enhancement of the } \\
\text { behaviour of SCC fly ash } \\
\text { hydraulic lime concrete. } \\
\text { of SCC fly ash hydraulic } \\
\text { lime concrete had reduced } \\
\text { filling capacity and fluidity } \\
\text { than other mixes. }\end{array}$ \\
\hline 5. & Liu (2010) [6] & $\begin{array}{l}\text { - Investigated SCC with up to } \\
80 \% \text { replacement of cement } \\
\text { by fly ash in mixtures } \\
\text { attuned to show constant } \\
\text { fresh concrete properties. } \\
\text { - Results revealed that SCC } \\
\text { with up to } 80 \% \text { cement } \\
\text { replaced by fly ash was } \\
\text { likely to be manufactured. } \\
\text { - To keep the filling ability } \\
\text { constant, replacement of } \\
\text { cement with fly ash was } \\
\text { accompanied by an } \\
\text { increase in water/powder } \\
\text { ratio and a decrease in the } \\
\text { dosage of superplasticiser. } \\
\text { It was revealed through the } \\
\text { experiments conducted } \\
\text { that fly ash had negative } \\
\text { impact on passing ability, } \\
\text { consistence retention and } \\
\text { the strength. }\end{array}$ \\
\hline 6. & \begin{tabular}{l}
\multicolumn{2}{c}{ Malagavelli } \\
and Rao \\
$(2010)$
\end{tabular} & $\begin{array}{l}\text { - Used High Density Poly } \\
\text { Propylene (HDPP) fibres } \\
\text { and Polyethylene } \\
\text { Terephthalate (PET) fibres } \\
\text { in concrete slabs. } \\
\text { - Noticed rise in ultimate } \\
\text { load carrying capacity of } \\
\text { the concrete, compressive } \\
\text { as well as flexural strengths } \\
\text { in comparison to the high } \\
\text { performance concrete. }\end{array}$ \\
\hline
\end{tabular}

\begin{tabular}{|c|c|c|}
\hline 7 & $\begin{array}{l}\text { Bhogayata et } \\
\text { al. (2011) [7] }\end{array}$ & $\begin{array}{l}\text { - Experimentally investigated } \\
\text { the viability of polyethylene } \\
\text { post-consumer waste used for } \\
\text { food packaging along with fly } \\
\text { ash. } \\
\text { - They added plastic waste in } \\
\text { fibre arrangement from } 0 \% \text { to } \\
1.5 \% \text { by volume of concrete } \\
\text { plus variation of fly ash from } \\
0 \% \text { to } 30 \% \text { by volume of } \\
\text { concrete. } \\
\text { To assess the impact of chemical } \\
\text { attack, different curing } \\
\text { conditions were used and the } \\
\text { corresponding alteration in the } \\
\text { compressive strength of } \\
\text { concrete mix were found out. }\end{array}$ \\
\hline 8. & $\begin{array}{l}\text { Rai et al. } \\
(2012)[8]\end{array}$ & $\begin{array}{l}\text { - The study was conducted on } \\
\text { the concrete mixes in which } \\
\text { there was a partial } \\
\text { replacement of fine } \\
\text { aggregates by waste plastic } \\
\text { flakes in changing } \\
\text { percentages by volume of } \\
\text { concrete. } \\
\text { - The concrete mixes both with } \\
\text { and without superplasticizer } \\
\text { were tested at room } \\
\text { temperature. } \\
\text { The results revealed that there } \\
\text { was a decrease in workability } \\
\text { and compressive strength } \\
\text { because of the partial } \\
\text { replacement of fine aggregates } \\
\text { by waste plastic and this } \\
\text { reduction was minimal without } \\
\text { super-plasticizer and was } \\
\text { improved with the addition of } \\
\text { super-plasticizer. }\end{array}$ \\
\hline 9. & $\begin{array}{l}\text { Kanellopoul } \\
\text { os et al. } \\
(2012)[14]\end{array}$ & $\begin{array}{l}\text { - Found out the durability of } \\
\text { SCC by employing the } \\
\text { following tests: sorptivity, } \\
\text { porosity and chloride ion } \\
\text { permeability } \\
\text { - The test results of SCC were } \\
\text { then compared with the } \\
\text { corresponding parameters of } \\
\text { normal concrete. } \\
\text { - Results indicated a } \\
\text { correlation between the } \\
\text { different durability indicators } \\
\text { for the definite filler additives } \\
\text { utilized in the mix designs. } \\
\text { The correlation was used to } \\
\text { evaluate the durability of SCC } \\
\text { without the necessity to count on } \\
\text { time intensive artificial } \\
\text { weathering experimental }\end{array}$ \\
\hline
\end{tabular}




\begin{tabular}{|c|c|c|}
\hline & & process. \\
\hline 10. & $\begin{array}{l}\text { Ghernouti et } \\
\text { al. } \\
{[10]}\end{array}$ & $\begin{array}{l}\text { - Tested the fresh as well } \\
\text { hardened properties of SCC } \\
\text { comprising of plastic bag } \\
\text { waste fibres (PBWF). } \\
\text { - The preparation of the fibres } \\
\text { were carried out by recycling } \\
\text { of the waste material such as } \\
\text { plastic bags. } \\
\text { - The study was carried out on } \\
14 \text { mixtures of SCC having } \\
0.40 \text { of w/c ratio. Out of } \\
\text { these, } 12 \text { SCC mixtures with } \\
\text { plastic bag waste fibre by } \\
\text { fluctuating the length } \\
\text { of fibres ( } 2,4 \text { and } 6 \mathrm{~cm} \text { ). } \\
\text { Test results revealed that } \\
\text { mixtures based on PBWF } \\
\text { with a length of } 2 \mathrm{~cm} \text {, met the } \\
\text { conditions of } \\
\text { self-compactability } \\
\text { irrespective of the fibres } \\
\text { content. }\end{array}$ \\
\hline 11. & $\begin{array}{l}\text { Massana et } \\
\text { al. } \quad(2018) \\
{[21]}\end{array}$ & $\begin{array}{l}\text { - Studied the impact of binary } \\
\text { and ternary mixtures of } \\
\text { nano-silica and micro-silica } \\
\text { on the durability of a HPSCC. } \\
10 \text { blends were made: one } \\
\text { without additions as control } \\
\text { mix, three with } 2.5 \%, 5 \% \text { and } \\
7.5 \% \text { of nano silica, three } \\
\text { more with } 2.5 \% \text {, 5\% and } \\
7.5 \% \text { of micro silica and three } \\
\text { using both admixtures, with } \\
2.5 \% / 2.5 \% \text {, 5\%/2.5\% and } \\
2.5 \% / 5 \% \text {, of nano silica and } \\
\text { micro silica, respectively. } \\
\text { The highest compressive } \\
\text { strength is attained in the } \\
\text { ternary admixture with } \\
2.5 \% / 2.5 \% \text {. }\end{array}$ \\
\hline 12. & $\begin{array}{l}\text { Ghorpade et } \\
\text { al. } \quad(2018) \\
{[27]}\end{array}$ & $\begin{array}{l}\text { - Studied chloride resistance of } \\
\text { waste plastic fibre reinforced } \\
\text { SCC. } \\
\text { - SCC mixes with fluctuating } \\
\text { percentages of waste plastic } \\
\text { fibres } 0.0 \%, 0.25 \%, 0.5 \% \text {, } \\
0.75 \%, 1.00 \%, 1.1 \%, 1.2 \% \text {, } \\
1.3 \% \text { and } 1.4 \% \text { were } \\
\text { established for M40 grade } \\
\text { concrete. } \\
\text { The concrete cubes and } \\
\text { cylinders were immersed in } \\
5 \% \text { magnesium chloride } \\
\text { solution for } 30 \text { days, } 60 \text { days } \\
\text { and } 90 \text { days. } \\
\text { The degree of chloride attack } \\
\text { was assessed by estimating } \\
\text { the decrease in compressive } \\
\text { strength, split tensile }\end{array}$ \\
\hline
\end{tabular}

\begin{tabular}{|c|c|c|}
\hline & & $\begin{array}{l}\text { strength and percentage loss } \\
\text { of weight of the specimen. } \\
\text { - Results revealed that } \\
\text { maximum compressive } \\
\text { strength and split tensile } \\
\text { strength were attained for } 1 \% \\
\text { replacement with plastic } \\
\text { fibre. } \\
\text { - Percentage loss of weight, } \\
\text { loss in compressive strength } \\
\text { and chloride penetration } \\
\text { reduced as the percentage } \\
\text { of fibre was enhanced. }\end{array}$ \\
\hline 13. & $\begin{array}{l}\text { Mohammed } \\
\text { et al. (2019) } \\
{[28]}\end{array}$ & $\begin{array}{l}\text { - Studied mechanical strength } \\
\text { of concrete for pavement } \\
\text { quality when mixed with rice } \\
\text { straw ash (RSA) and } \\
\text { micro-silica (MS). } \\
\text { - } 9 \text { mixes were made by partial } \\
\text { replacement of OPC with } \\
\text { micro-silica (2.5\%, 5\%, } \\
7.5 \% \text {, and 10\%), RSA (10\%) } \\
\text { and RSA-MS composite } \\
\text { (5\%-5\%, 5\%-7.5\%, } \\
10 \%-5 \% \text { and } 10 \%-7.5 \%) \text {. } \\
\text { Maximum enhancement was } \\
\text { seen when OPC was partially } \\
\text { replaced by 7.5\% of } \\
\text { micro-silica and 5\%-7.5\% in } \\
\text { case of RSA-MS composite. } \\
\text { All the mix revealed } \\
\text { improved strength in } \\
\text { comparison to the normal } \\
\text { mix. }\end{array}$ \\
\hline 14. & $\begin{array}{l}\text { Al-Hadithia } \\
\text { et al. (2019) } \\
{[12]}\end{array}$ & $\begin{array}{l}\text { - PET fibres with an aspect } \\
\text { ratio of } 28 \text { were added from } \\
\text { waste plastic to SCC. } \\
\text { One control mix was } \\
\text { developed using which all } \\
\text { other mixes were developed. } \\
\text { - } 8 \text { SCC mixes containing } \\
\text { diverse volumetric ratios of } \\
\text { plastic fibres percentages } \\
\text { (0.25\%, 0.5\%, 0.75\%, 1\%, } \\
1.25 \%, 1.5 \%, 1.75 \% \text { and } \\
2 \%) \text { were developed. } \\
\text { - The behaviour of SCC slabs } \\
\text { under impact loading was } \\
\text { assessed. } \\
\text { A substantial enhancement } \\
\text { was seen in the resistance to } \\
\text { impact load and energy } \\
\text { absorption capacity of slabs } \\
\text { containing PET fibres. } \\
\text { The increase in the time of } \\
\text { maximum deflection for the } \\
\text { concrete mixes containing PET } \\
\text { fibres improved significantly } \\
\text { showing an improvement in the }\end{array}$ \\
\hline
\end{tabular}




\begin{tabular}{|l|l|}
\hline & $\begin{array}{l}\text { capacity of SCC to absorb } \\
\text { further energy under low } \\
\text { velocity impact. }\end{array}$ \\
\hline
\end{tabular}

\section{DISCUSSION AND CONCLUSION}

After critically reviewing all the literatures, following points have been drawn for discussion point of view.

- Very less volume of research work is available on utilization of waste polythene in conventional concrete as well as SCC.

- No substantial work has been done on utilization of waste polythene with micro silica in SCC but some researchers used it in conventional (normal) concrete.

- A few studies have stated positive results towards the mechanical properties (compressive strength and flexural strength) of concrete while no literature is available taking into account its initial cost and the durability of such concrete.

Thus, there is a wide scope of study related to utilization of waste polyethene, red mud, fly ash and micro-silica and other related additives in SCC. This will help to assess the various mechanical, physical, micro-structural and durability properties of SCC with different additives.

\section{REFERENCES}

[1] Gupta, S. 2019. Recent Advances in Self-Compacting concrete. New Building Materials \& Construction World (NBM\&CW), 24(7):178-185.

[2] Gupta, S., 2016. A Review on the use of Micro-silica and Nano-silica in SCC, New Building Materials \& Construction World (NBM\&CW), 22 (2): 131-137.

[3] Persson B., 2001. A comparison between mechanical properties of self-compacting concrete and the corresponding properties of normal concrete, Cement and Concrete for Research, 31:193-98.

[4] Felekoglu B, Turkel S, and Baradan B. , 2005. Effect of w/c ratio on the fresh and hardened properties of SCC, Building and Environment Research,35: 373-79.

[5] Grdic Z., Despotovic I., and Topliciccurcic G., 2008. Properties of self-compacting concrete with different types of additives, Architecture and Civil Engineering, $6(2): 173-77$.

[6] Liu M., 2010. Self-compacting concrete with different levels of pulverized fuel ash, Construction and Building Materials, 24:1245-52.

[7] Bhogayata, A., Shah, K. D., Vyas, B. A. and Arora N. K., 2012. Feasibility of wastes metallized polythene used as concrete constituent. International Journal of Engineering and Advanced Technology (IJEAT), 1(5):1-10

[8] Rai, B., Rushad, S. T., Kumar, B. and Duggal, S. K. 2012. Study of wastes plastic mix concrete with plasticizer. International Scholarly Research Network ISRN Civil Engineering, Article ID 469272, doi:10.5402/2012/469272.

[9] Chhotu, A.K. and Gupta, S., 2013. Use of Waste Plastic in Bituminous Concrete Mixes for Construction of Flexible Pavements: Step towards Waste Minimization. National Conference on Recent Trends in Innovation in Civil Engineering held at BRCM CET, Bahal: 151-154.

[10] Ghernouti, and Youcef,, 2015. Fresh and hardened properties of self-compacting concrete containing plastic bag waste fibers (WFSCC). Construction and Building Materials, 82:89-100.

[11] Singh N., and Singh S.P., 2016. Carbonation and electrical resistance of self-compacting concrete made with recycled concrete aggregates and metakaolin, Construction and Building Materials, 121: 400-09.

[12] Al-Hadithi, A.I., Noaman, A.T. and Mosleh, W.K., 2019. Mechanical properties and impact behavior of PET fiber reinforced self-compacting concrete (SCC). Composite Structures, 224: 111-21.

[13] Uysal M. and Yilmaz K., 2011. Effect of mineral admixtures on properties of self-compacting concrete, Cement \& Concrete Composites, 33: 771-76.

[14] Kanellopoulos, A. , Petrou M, and Ioannou I., 2012. Durability performance of self-compacting concrete, Construction and Building Materials, 37:320-25.

[15] Aslani F. and Nejadi S, 2012. Mechanical properties of conventional and self-compacting concrete: An analytical study, Construction and Building Materials, 36: 330-47.

[16] Todorova E., Chernev G., and Markov P., 2013. Influence of metakaolinite and stone flour on the properties of self-compacting concrete, Journal of Chemical Technology and Metallurgy, 48(2): 196-201.

[17] Shetty K, Nayak G, and Shetty R, 2014. Self-Compacting Concrete Using Red Mud And Used Foundry Sand, International Journal of Research in Engineering and Technology,3: 709-11.

[18]Rich D, Goodier C, Glass J, Gibb A, and Sander G, 2015. Optimising construction with selfcompacting Concrete, Proceedings of the Institution of Civil Engineers - Construction Materials, 170 (2):104-14

[19] Kapoor K., Singh S., and Singh B., 2016. Durability of self-compacting concrete made with Recycled Concrete Aggregates and mineral admixtures, Construction and Building Materials, 128: 67-76.

[20] Li H, Huang L, Yongjiang X, Zhonglai Y, and Wang Z, 2017. Effect of water-powder ratio on shear thickening response of SCC, Construction and Building Materials, 131:585-91.

[21] Massana J, Reyes E, Bernal J, León N, and Sánchez-Espinosa E., 2018. Influence of nano-and micro-silica additions on the durability of a high-performance self-compacting concrete, Construction and Building Materials, 165:93-103.

[22] Bouzoubaa N. and Lachemi M., 2001. Self-compacting concrete incorporating high volumes of class F fly ash Preliminary results, Cement and Concrete Research, 31:413-20.

[23] Safiuddin M, West J.S., and Soudki, K.A., 2008. Durability performance of Self- compacting concrete, Journal of applied Sciences Research, 4(12): 1834-40. 
[24] Valcuende M. and Parra C., 2010. Natural carbonation of self-compacting concretes, Construction and Building Materials, 24:848-53.

[25] Druta C, Wang L, and Lane D, 2014. Tensile strength and paste-aggregate bonding characteristics of self-consolidating concrete. Construction and Building Materials, 55:89-96.

[26] Varghese M., 2017. Partial Replacement of Cement using Red Mud in SCC, International Journal of Innovative Research in Science, Engineering and Technology, 6(5): 8333-37.

[27] Ghorpade, V.G. and Rao, H.S., 2018. The Behaviour of Self Compacting Concrete With Waste Plastic Fibers When Subjected To Chloride Attack. Materials Today: Proceedings, 5(1):1501-08.

[28] Mohammed, M.K., Al-Hadithi, A.I. and Mohammed, M.H., 2019. Production and optimization of eco-efficient self-compacting concrete (SCC) with limestone and PET. Construction and Building Materials, 197: 734-46.

\section{ABOUT THE AUTHORS}

Sakshi Gupta, is presently working as Assistant Professor, Department of Civil Engineering, Amity School of Engineering and Technology, Amity University Haryana, India. Her areas of interest includes construction technology and management, BIM, concrete technology, Soft computing techniques in Civil Engineering applications and sustainable construction. She has published more than 40 research articles, paper, book chapters and books of National and International repute. She is the editorial as well as reviewer board member of many international journals.

Rishabh Mahure is presently working as Assistant Professor, Department of Civil Engineering, Noida International University, Gr. Noida, UP. He is M.Tech in Construction Technology and management and has an expertise in materials related with concrete. He has published many research papers in journals of national and international repute.

Ankit Batra, is working as Assistant Professor, Department of Civil Engineering, Amity School of Engineering and Technology, Amity University Haryana, India. His area of specialization includes design and analysis of structures. He is competent in various software skills such as ETabs, STAADPro to name a few. He has published various papers in journals of national and international repute. 